\title{
Against the Mainstream: Muhammad Abduh's Reading of Q1:7 and its Implications for Current Muslim-Jewish Relations
}

\section{Abduh and the Tafsir al-Manar}

Egyptian scholar Muhammad Abduh (1849-1905) is of course a well-known figure in Muslim circles and beyond. ${ }^{1}$ It is suffice to mention that he is considered the founding father of Islamic Modernism, the school of thought that preached a deep reform of the dominant attitudes of Muslims, in order to narrow significantly the gap between Islamic values and Western thought. This led to his readiness to borrow ideas and practices from the West, like democracy, rule of law, educational reform, free thought and research, improving the status of women, and relations with believers from other faiths.

He was an al-Azhar graduate and then a senior teacher at that institute, and in his last years, he was also the Mufti of Egypt. An important pillar of his project was to prove that all these changes are authorized and even mandated by Islamic sources-the Qur'an, Hadith, and the models of behavior exemplified by the Salaf-the ancient fathers of Islam, roughly, the first three generations after the Prophet. Those sources are to go through a process of Ijtihad, a re-interpretation; thus, they will be totally competent to deal with the challenges confronting Muslims in the modern era.

The main tool used by Abduh to spread his views was the periodical alManar [The Lighthouse] established by his disciple Rashid Rida in 1898. After Abduh's death, al-Manar continued its regular publication until Rida's death, in

1 Abduh's Ideas and impact are discussed in almost every book on modern Islam. The only biography dedicated to him is M. Sedgwick, Muhammad Abduh (Oxford: Oneworld, 2009), where there is only a brief mention of his exegetical contribution. This is discussed, also briefly, in R. Wielandt, "Exegesis: Modern," in Encyclopaedia of the Qur'ān, ed. Jane Dammen McAuliffe (Leiden: Brill, 2002), 2:124-40. For another assessment of Abduh's contributions and an interesting correspondence between him and Leo Tolstoy, see my review of Sedgwick's book, I. Shrenzel, "Haadam ba laolam kdei le-hatzmiah yeda" ["Man Came to the World to Create Knowledge”], Haaretz, January 13, 2012. http://www.haaretz.co.il/literature/safrut/print/1.1616379 [Hebrew].

Ә OpenAccess. ( 2020 Israel Shrenzel, published by De Gruyter. (cc) BY-NC-ND This work is licensed under the Creative Commons Attribution-NonCommercial-NoDerivatives 4.0 License. 
1935. Rida, as is well known, came to be a very important scholar on his own merit.

From time to time, al-Manar also contained Abduh's lectures on the first four Suras of the Qur'an. He presented them orally to a group of his students almost every week, and they were transformed into a written version by Rida, which in some cases added his remarks, clearly distinguishable from Abduh's words. After Abduh's death, Rida continued the Tafsir, namely exegesis, now well known as Tafsir al-Manar in 12 tomes, through Sura 12.

In line with his life-long project, described briefly above, the preface to the Tafsir states:

This is the only Tafsir that combines tradition and rational thought ... that clarifies that the Qur'an is the guide for Humanity at all times, and evaluates the situation of the Muslims in current times, including their deviation from the rightful guidance of the Qur'an. ${ }^{2}$

Abduh's ideas were not fully accepted even by those who saw him as their mentor, or wished to portray him as such. Actually, two trends can be traced among them: One that adopted a very pro-Western, even secular approach, and another, most prominent among its supporters are Rida himself, and the "Muslim Brothers," that preached a very suspicious attitude towards Western values, rejected what they perceived as the "Western cultural invasion" and prioritized the Jihad against colonialism and Zionism, over internal reforms and changes. In recent years, in the background of the tremendous ideological and political turmoil in the Arab and Muslim world, and more than one hundred years after his passing away, we witness a certain measure of revival regarding Abduh's acceptance. There is now a growing readiness to reconsider his moderate ideas, as will be demonstrated later. Because the core issue of the article is Abduh's attitude of a "Jewish" verse from the Qur'an, we shall present now the basic attitudes of the Qur'an toward the Jews.

2 M. Abduh and R. Rida, Tafsir al-Manar, 12 vols. (Beirut: Dar al-Marifa), 1:1. 


\section{Some Verses regarding the Jews and Short Remarks on these Verses ${ }^{3}$}

When the Qur'an relates explicitly to the Jews, the reference to them is divided into three terms: Children of Israel ("Banu Israil"), the Jews ("al-Yahud"), and "the People of the Book," a term that relates to Jews and Christians alike. The first category deals with the biblical Israelites and almost always echoes the biblical story, in many cases adding materials from the vast Jewish literature of interpretations and legends that do not appear in the Bible, mostly from the Midrash.

The vast majority of the verses are utterly pejorative, and it is easy to understand why and how they were used to justify antisemitic Muslim attitudes, past and present. In the first category, the stories stress the severe sins of the Israelites, mainly their disobedience of God and their prophets, and the harsh punishments that were their share throughout their long history of suffering. Some of the punishments are about to haunt them forever, according to some verses. The tales are shaped so that a similarity is maintained between the fate of the biblical Prophets and the situation of Muhammad vis-à-vis the heathen Arabs and the Jews that rejected him. This setting puts Muhammad on equal footing with Moses and Jesus, for example, and also provides him with a divine promise that in spite of all obstacles, his way and message would finally prevail.

In the second and third categories, harsh allegations are directed against the Jews who confronted Muhammad and refused to join his new religion. These are basically verses of bitter polemic regarding the beliefs and actions of those Jews. We have scant information about the nature of the Jews in Arabia at the time, but the most-accepted assumption is that they were mainstream Rabbinical Jews who refused to admit that Muhammad could be a true prophet, because the firm Jewish tradition is that Prophecy stopped completely in the era of the Second Temple. More than that, even if Muhammad were to be a prophet for the Arabs, why should it oblige the Jews to convert and join his community? So the most frequent guilt of the Jews of that time is the intentional falsification of their own Scriptures, thus denying the mission of Muhammad that is allegedly mentioned there.

3 This section is based mostly on U. Rubin, "Jews and Judaism," in Encyclopaedia of the Qur'än, ed. Jane Dammen McAuliffe (Leiden: Brill, 2003), 3:21-34, and on M. Lecker, Muhammad ve Hayehudim [Muhammad and the Jews] (Jerusalem: Yad Ben Tzvi, 2014) [Hebrew]. This book is a very comprehensive, detailed, and updated analysis of the actual reality and events in the framework of Muhammad's relations with the Jews of al-Madina and its vicinity. It proves, inter alia, how important the social and economic reasons were for the animosity between the two parties. An English version will be published, hopefully, in the near future. 
As a rule, the Qur'an lacks any mention of the specific context of the revelation. Nevertheless, the "Jewish" verses usually conform to the basic historical sequence created by Muslim tradition and widely accepted today by Western scholarship. So, roughly speaking, we find a few tolerant verses, dating probably to the period when Muhammad still hoped to gain the support of the Jews and/or lacked the power to act directly against them, using violent means. They are relevant also to the period when he wished to convince his own Meccan tribe that he was God's Messenger. Even then, and also in further stages, negative verses regarding the Israelites are included. The polemical verses date mainly to the years after the Hijra to al-Medina in 622, when he encountered in the city and its surroundings a tangible Jewish, Arabicized communities or tribes. Gradually, Muhammad lost hope to gain Jewish support and paved the way to the expulsion of many Jewish communities, to the looting of their land and properties and to the slaughter committed against the males of the tribe of Quraiza. The main pretext for these measures was the claim that the Jews did not live up to the obligations they took upon themselves in the treaties they had signed with the Arab tribes, who now became loyal allies of Muhammad. Hence, some verses easily fit with the actual siege and fight by the Muslims against the Jews and stress the divine encouragement to their anti-Jewish military campaigns.

In what follows there is a small selection of relevant verses.

\section{Anti-Jewish Verses ${ }^{4}$}

The people of Moses took to them, after him, of their ornaments a Calf-a mere body that lowed. Did they not see it spoke not to them, neither guided them upon any way? Yet they took it to them, and were evildoers. (7:145-146)

So, for their breaking the compact, and disbelieving in the signs of God, and slaying the Prophets without right, and for their saying, "Our hearts are uncircumcised"-nay, but God sealed them for their unbelief, so they believe not, except a few. (4:154-155)

And We decreed for the Children of Israel in the Book: "You shall do corruption in the earth twice." ...

So, when the promise of the first of these came to pass, We sent against you servants of Ours, men of great might, and they went through the habitations, and it was a promise performed.

Then We gave back to you the turn to prevail over them....

Then, when the promise of the second came to pass, We sent against you Our servants to discountenance you, and to enter the Temple, as they entered it the first time. (17:4-7)

4 All Quranic verses are from A. J. Arberry, The Koran Interpreted (London: Oxford University Press, 1964). 
People of the Book, now there has come to you Our Messenger, making clear to you many things you have been concealing of the Book, and effacing many things. (5:19)

The Jews say, "Ezra is the Son of God"; the Christians say, "The Messiah is the Son of God.” ... God assail them! How they are perverted!

They have taken their rabbis and their monks as Lords apart from God. (9:30-31)

Thou wilt surely find the most hostile of men to the believers are the Jews and the idolaters. (5:85)

Say: "People of the Book, do you blame us for any other cause than that we believe in God, and what has, been sent down to us, and what was sent down before, and that most of you are ungodly?” ...

Whomsoever God has cursed, and with whom He is wroth, and made some of them apes and swine, and worshippers of idols-they are worse situated, and have gone further astray from the right way. (5:64-65)

And He brought down those of the People of the Book who supported them from their fortresses and cast terror in their hearts; some you slew, some you made captive. And He bequeathed upon you their lands, their habitations, and their possessions, and a land you never trod. God is powerful over everything. (33:26)

\section{Tolerant Verses}

The number of these kinds of verses is significantly lower than the hostile verses, mentioned above. Many classical Muslim scholars and jurists in the Middle Ages used to undermine their importance and claimed that most of these verses were abrogated by the more militant ones. Nevertheless, they do form part of the Holy Scripture. As is well known, modern Muslim thinkers and commentators revive their status and validity. Those intellectuals call for adhering to these moderate verses, provided that they are suitable to the current needs of the Muslims. Here is a selection of relevant verses.

If God had willed, He would have made you one nation; but that He may try you in what has come to you. So be you forward in good works; unto God shall you return. (5:54)

No compulsion is there in religion. Rectitude has become clear from error. So whosoever disbelieves in idols and believes in God, has laid hold of the most firm handle, unbreaking. (2:257)

Say: "O unbelievers, I serve not what you serve

And you are not serving what I serve,

Nor am I serving what you have served,

Neither are you serving what I serve

To you your religion. and to me my religion!” (109:1-5) 


\section{Surat al-Fatiha-Main Features}

As we shall deal now with Abduh's interpretation of the first chapter of the Qur'an, we present first its translation and some of its main features.

\section{The Opening}

1 In the Name of God, the Merciful, the Compassionate

2 Praise belongs to God, the Lord of all Being

3 The All-merciful, the All-compassionate

4 The Master of Day of Doom

5 Thee only we serve, to thee only alone we pray for succor

6 Guide us in the straight path

7 The path of those whom Thou art blessed, not of those against whom Thou art wrathful, nor of those who are astray

Centuries of analysis, both Islamic and non-Islamic, pointed to the unique characteristics of this Sura. The Suras are largely organized from longest to shortest, save some minor exceptions, but al-Fatiha, though very short, is the first one. It is actually a prayer to God, while the belief that the whole Qur'an is God's word is a basic pillar in Islamic doctrine. Hence, the obligatory Muslim explanation that it reflects God's command to Muslims how to pray to Him in the proper way. Because Muslims do not have a prayer book, like Sidur or Mahzor in Judaism, alFatiha is the main part of the Muslim daily prayer and is also recited on many other occasions in individual and community life, from cradle to grave.

Regarding its content, the first six verses are quite clear. They are a direct speech to God, praising him and asking for His help and guidance to the straight path. As already noted by many, the Sura contains some expressions that are similar to Biblical ones, has no mention of the Prophet, and can be easily integrated to the traditional Jewish Sidur, an idea already raised by Jews who are active in Jewish-Muslim dialogue. ${ }^{5}$

The main exegetical task is concerned with v. 7-who are the three groups that are mentioned there? The majority of Muslim exegetics, beginning from Tafsir al-Tabari in the tenth century, the most esteemed in Muslim tradition, going through the short and most popular Tafsir al-Jalalayn in the fifteenth century, adopt the following categorization: the "blessed ones" are the Muslims; those

5 For a quite detailed analysis of the first Sura, see W. Graham, "Fatiha," in Encyclopaedia of the Qur'ān, ed. Jane Dammen McAuliffe (Leiden: Brill, 2002), 2:188-92. 
who suffered God's wrath are the Jews; and those who are astray are the Christians. ${ }^{6}$ Accordingly, every Muslim begs God to enjoy his grace that is allocated specifically to Muslims and to differentiate him sharply from the past and future of Jewish and Christian history and destiny. As noted recently by the Israeli scholar Avi Elqayam in his comprehensive essay on al-Fatiha, this line of explanation is popular among modern scholars as well, especially those who belong to the fundamentalist-radical circles, most prominent among them is Sayyid Qutb (1906 -1966), widely considered the "Spiritual Father" of all Jihadist movements, including al-Qaida and IS. ${ }^{7}$

More than that, it is obvious that if we ask the ordinary Muslim for the meaning of the verse, it is likely that he/she will cite the meaning just presented. Admittedly, this understanding of the verse is in line with the spirit and content of most, though not all, Qur'anic attitudes to the Jews, as will be presented in the appendix to this article. No doubt, this common, almost intuitive understanding contributed its share to Muslim antisemitism, old and new.

On the other hand, Elqayam also proves that in classical Islam, the non-exclusive and non-self-praising explanation of the verse was clearly in the minority but not absent altogether. Especially in Sufi circles, well exemplified in the writings of Abu-Hamed al-Ghazali (d. 1111) and Ibn al-Arabi (d. 1260), a more universal, ecumenical approach is adopted. It is probable that these scholars and their likes had significant influence on Abduh's attitude. ${ }^{8}$

\section{Abduh's Commentary of $1: 7$}

Abduh begins by presenting the popular explanation of the verse and then asserts that this Sura was the first of God's revelations to the Prophet Muhammad. He bases this analysis on a tradition attributed to Ali, the cousin of Muhammad, and later his son-in-law. Abduh knew of course that it is not the mainstream view that usually considers Sura 96 as the first one, but this assertion is critical to the core of his argument: it was revealed in the very early stage in the development of Islam, so it is impossible that the prayer is ordered to ask God to lead him to the Muslim path. At that time, the Muslim path was doing its first and hesitant

6 J. al-Din al-Mahalli and J. al-Din al-Suyuyti, Tafsir al-Jalalayn (Cairo: Dar al-Nashr, 1968). 7 A. Elqayam, “al-Fatiha-Kriot Kuraniyot” [“Al-Fatiha-Quranic Readings”], in Hamizrah kotev at atzmo [The East Writes Itself], ed. H. Pdayah (Tel Aviv: Gomeh, 2015), 209 [Hebrew].

8 Elqayam, "al-Fatiha," 183-87. 
steps, and of course very far from being coherent, since it would be crystallized only later, after many revelations yet to happen. ${ }^{9}$

So it is clear, says Abduh, that the "blessed ones" are not the Muslims; indeed the verse refers to the "prophets, righteous men, and the martyrs from previous nations, that preceded Islam." He mentions that three quarters of the Qur'an are dedicated to stories that relate to these nations, so studying carefully their beliefs and heresies would lead to the straight path. Therefore, those who suffered God's wrath and those who went astray are to be identified with individuals from "previous nations" but not with large collective groups. Or in other words-they might be Jews and Christians but not the Jews and the Christians as unified, collective entities.

On this point, Abduh pauses his main thesis by inserting a "modernist" passage regarding an educational issue that was very dear to him-the importance of learning history. Mentioning it in his commentary of the first Sura reflects his long fight for including history in the curriculum of all levels of education and especially in al-Azhar:

[E]mbarrassment and bewilderment will be the share of those who hear that many of the clergies of a nation that this is her Book, use religious claims to block the study of history and assert falsely that there is no need to do that. They raise these claims while the Qur'an states that knowledge of the situation of the nations is among the most important issues that this religion calls for.

Then he goes back to the core of his commentary and poses the following crucial question:

How could it be that God commands us to follow the way of those who preceded us, while we have now legal commands and guidelines that they did not have, and therefore our laws should be considered more perfect and more suitable to our times than theirs?

And his answer is very clear:

[T]he Qur'an himself relates to that question by explicitly stating that the religion of God is one in all nations, and that the legal commands change from one religion to another only in detail, according to the change of times, but there is no change in the foundations, in the basic principles-belief in God and in the Prophets, in rejecting evil, and striving towards the best of virtues is similar in all religions.

And the resulting conclusion is clear:

9 For the complete text of Abduh regarding this verse, see Abduh, al-Manar, 1:66-68. 
God ordered us to look carefully at the history of these people, the "blessed ones," and to imitate them upon the principles of the Good. The details of their general commands are to be learnt from our law and from our prophet.

It is worth noting which Qur'anic verses Abduh presents to corroborate his arguments. The first one is a divine command to speak directly to the Jews and to the Christians:

Say, People of the Book! Come now to a word common between us and you, that we serve none but God, and that we associate not with Him, and do not some of us take others as Lords apart from God (3:56).

The second one contains the most detailed list, in one verse, of biblical figures, considered by the Qur'an as prophets and messengers:

We have revealed to Thee as We have revealed to Noah, and the Prophets after him, and We revealed to Abraham, Ishmael, Isaac, Jacob, and the Tribes, Jesus and Job, Jonah and Aaron and Solomon and we gave David the Psalms, and Messengers we have already told Thee of before, and Messengers we have not told Thee of (4:162).

The choice of both verses speaks for itself: it combines a very positive attitude towards previous prophets, because they are probably according to the author the "blessed ones" mentioned in Sura 1 and a plea for a common denominator with the other monotheistic faiths, a notion considered by Abduh to be relevant also to his own times.

The measure of the innovation in Abduh's commentary is clear when we notice that Rida added a correction some thirty pages after Abduh's words. He claims that there are several credible Hadiths that confirm the traditional categorization. ${ }^{10}$

\section{More Examples of Abduh's Attitude}

A full analysis of Abduh's "Jewish" attitudes in the Tafsir and in his other writings is a task yet to be fulfilled. But still, reviewing even a portion of his written corpus traces a clear similarity to his ideas presented above.

A good example is Abduh's commentary to the following verse:

10 Abduh, al-Manar, 1:97-98. 
You are the best nation ever brought forth to men, bidding to honor and forbidding dishonor, and believing in God. (3:106)

He strives to confine the prestigious title of "best nation" to the prophet and his followers that were active with him in his presence. Actually, he stresses the nuance that those who converted to Islam in an early stage, but did not meet the Prophet in person, are not included in that group. ${ }^{11}$ This explanation contradicts of course a much more comprehensive definition adopted by Tafsir al-Jalalayn that says that "the Nation of Muhammad," apparently in general, merits this epithet. $^{12}$

Another characteristic of Abduh's commentary is to understand the term Islam not as the established concrete religion but to stick to its literal meaning-"submission of the soul and the practical adherence to the orders of God." This is clear from his understanding of 3:17 that says: "The true religion with God is Islam."13

In one of his famous essays, Abduh mentions "Friendship with those who Differ in Faith" as one of the basic principles of Islam that his co-Muslims should adopt. He mentions there the legal permission for a Muslim to marry a Jewish or Christian woman, even if she did not convert. ${ }^{14}$ In his popular Fatwa, known as the Transwaal Fatwa, he allowed South African Muslims to wear a Western styled hat, as long as it does not lead to heresy and also to eat meat slaughtered by Jews or Christians, even when the traditional Basmala, usually considered obligatory, was not recited during the act of slaughtering. ${ }^{15}$

\section{Abduh's Presence in the Current Religious Debate in Egypt}

The one-hundredth anniversary of Abduh's death in 2005 had gone almost entirely unnoticed, even in his homeland of Egypt. But he and his ideas came back to the public sphere, after the Arab Spring of 2011, and specifically in Egypt, after Abd-al-Fattah al-Sisi took over in 2013. One of al-Sisi's slogans

11 Abduh, al-Manar, 4:57-59.

12 al-Jalalayn, Tafsir.

13 Abduh, al-Manar, 3:257-59.

14 M. Abduh, Al-Islam Din al-Ilm wa al-Madaniya (Cairo: al-Majlis al-Aala Lishuun al-Islamiya, 1964), 109-11.

15 Sedgwick, Abduh, 97-99. 
and activities after consolidating his power was "The Renewal of Religious Discourse" ["Tajdid al-Hitab al-Dini”]. In the framework of a very intensive campaign to uproot the Muslim Brothers and their ideology that is conceived very pejoratively by the regime, al-Sisi and his aides recruited Abduh's moderate approach on a variety of issues as an alternative model. It is premature and indeed out of the scope of this paper, to evaluate the success of these relentless efforts. Seemingly the jury is still out.

Curiously enough, the very issue of Abduh's commentary on Sura 1 surfaced in the Egyptian popular media during 2017. Some prominent journalists noted that booklets distributed regularly at funerals and mourning gatherings contained the al-Fatiha with the traditional interpretation of the verses discussed here. More than that, it is stipulated in the preface that al-Azhar authorized these booklets. These journalists did not hide their harsh opinions against these booklets, and they also criticized al-Azhar for its authorization and mentioned that even past scholars and deans of the Institute voiced their reservations about the traditional, exclusivist frame of mind, regarding those verses. They also urged the adoption of Abduh's interpretation as the correct one and as the most suitable for the modern era, namely, that people will be judged according to the quality of their deeds and not according to their religious affiliation. One of the writers asked, for example, whether it is not more appropriate to understand the verse as promising that God's wrath would be directed against Muslims who burn churches, or indulge in drinking and gambling. "Why do we dismiss ideas of light and openness in favor of extreme and dark ones?" asked another article. The following saying sums up the spirit of the debate:

All religions should lead to the purpose for which they were revealed: to foster peace, compassion, co-existence and acceptance of the other. ${ }^{16}$

Another example of Abduh's re-emergence in Egyptian discourse is his recurrent mention, combined usually with his photo, in the pages of the monthly al-Hilal, one the most important Egyptian intellectual organizations, for the last 125 years. In several articles in 2017, he is portrayed as a symbol of a scholar and clergy that should be imitated in our times, in stark contradiction with the Muslim Brothers and other "extremists" that are severely denounced, including the accusation that Hasan al-Banna, the founder of the Brothers, was of Jewish ori-

16 For a detailed discussion of this debate, see "Bikoret Bemitzrayim" [“Criticism in Egypt”], MEMRI, 2017, http://www.memeri.org.il/cgi-webaxy/item?4481 [Hebrew]. 
gins, God Forbid. In one issue, he is on the cover, together with a few others, all of them entitled the "Knights of Thought," or "Knights of Consciousness."17

\section{Conclusion}

As we have seen before, the majority of the Qur'anic verses dealing with Jews are pejorative ones. And likewise more Muslim Scholars, even since the eighth century, endorse their relevant and valid interpretation as hostile to the Jews. The same goes for the reading of the seventh verse of al-Fatiha: the more popular reading perceives the Jews to be mentioned there in a negative manner. Abduh in this regard was among the first in modern times to challenge the accepted view and to offer a much more universalist approach to this verse and consequently a much more positive attitude toward the Jews. It is still a minority view today, but it seems to gain some traction among various audiences. This author is hopeful that together with the growing interest in Abduh's ideas and philosophy, also his specific reading of a major Qur'anic verse, would attract more and more supporters among Muslims.

Israel Shrenzel is an adjunct professor in the department of Arabic and Islamic Studies, in Tel-Aviv University.

\section{Bibliography}

\section{Primary Sources}

Abduh, Muhammad and Rashid Rida. Tafsir al-Manar. 12 vols. Beirut: Dar al-Marifa.

Abduh, Muhammad. Al-Islam Din al-Ilm wa al-Madaniya. Cairo: al-Majlis al-Aala Lishuun al-Islamiya, 1964.

al-Hilal Monthly. July 2017. Cairo: Dar al-Hilal, 2017.

al-Mahalli, Jalal al-Din and Jalal al-Din al-Suyuti. Tafsir al-Jalalayn. Cairo: Dar al-Nashr, 1968.

\section{Secondary Sources}

Arberry, Arthur J. The Koran Interpreted. London: Oxford University Press, 1964.

17 al-Hilal Monthly, July 2017 (Cairo: Dar al-Hilal, 2017). 
Elqayam, Avraham. "al-Fatiha-Kriot Kuraniyot” [“Al-Fatiha-Quranic Readings”]. In Hamizrah kotev at atzmo [The East Writes Itself], edited by Haviva Pdayah, 157-249. Tel Aviv: Gomeh, 2015 [Hebrew].

Graham, William. "Fatiha." In Encyclopaedia of the Qur'ān, edited by Jane Dammen McAuliffe, 2:188-92. Leiden: Brill, 2002.

Lecker, Michael. Muhammad ve Hayehudim [Muhammad and the Jews]. Jerusalem: Yad Ben Tzvi, 2014. [Hebrew]

N.N. "Bikoret Bemitzrayim” [“Criticism in Egypt”]. MEMRI, 2017. http://www.memeri.org.il/cgiwebaxy/item?4481 [Hebrew].

Rubin, Uri. “Jews and Judaism.” In Encyclopaedia of the Qur'ān, edited by Jane Dammen McAuliffe, 3:21-34. Leiden: Brill, 2003.

Sedgwick, Mark. Muhammad Abduh. Oxford: Oneworld, 2009.

Shrenzel, Israel. "Haadam ba laolam kdei le-hatzmiah yeda" ["Man Came to the World to Create Knowledge"]. Haaretz, January 13, 2012. http://www.haaretz.co.il/literature/sa frut/print/1.1616379 [Hebrew].

Wielandt, Rotraud. “Exegesis: Modern.” In Encyclopaedia of the Qur'ān, edited by Jane Dammen McAuliffe, 2:124-40. Leiden: Brill, 2002. 
